\title{
Use of Foley catheter as a flap retainer
}

\author{
Hemant Saraiya \\ Sushrut Plastic Surgery Research Center and Gujarat Cancer and Research Institute, Ahmedabad, Gujarat, India
}

Address for correspondence: Dr. Hemant Saraiya, 10, Avanti Apartments, Bhagvan Nagar No Tekro, Paldi, Ahmedabad - 380 007, Gujarat, India. E-mail: drhemantsaraiya@hotmail.com

\section{ABSTRACT}

Keeping skin graft or a flap adherent to the underlying surface can sometimes be a difficult job, particularly inside a cavity. Different methods have been used for this function with varying success but the search is still on for an ideal pressure dressing.

\section{KEY WORDS}

Foley catheter, flap retainer

\section{INTRODUCTION}

ver the years, pressure to keep a skin graft or flap firmly opposed to the underlying wound bed has been attempted with the help of a tight dressing, tie-over dressing, elastic bandage or adherent tape. Unfortunately, the pressure may not remain effective throughout, until complete healing occurs as is necessary. We present a case where an inflated Foley's Catheter was used to maintain gentle compression following reconstruction of an eye socket with a forehead flap.

\section{CASE HISTORY}

A 55 year-old female patient was referred to us with a raw area and discharge from the left eye socket. She had a history of swelling of the left upper alveolus and upper face for one year. She was diagnosed to have a squamous cell carcinoma of the left maxilla which had also involved the eyeball. Total left maxillectomy with left eye ball evisceration had been carried out three months earlier by the surgical oncology unit. The eye socket had been reconstructed with a split thickness skin graft. The take of the skin graft was partial and there were multiple raw areas with a purulent discharge. Repeated attempts to cover the defect with split thickness skin grafts had failed. A total forehead flap was advised by us. The flap surgery was also carried out by the surgical oncology unit itself. The patient was referred back to us after a month with a dirty foul-smelling discharge from the eye socket. On examination, the forehead flap was found to be non adherent to the socket walls [Figures 1 and 2]. There was a cavity between the flap and socket walls. After detaching the flap, thorough debridement was carried out and all infected granulations were removed [Figure 3]. The flap was reintroduced into the socket and the flap margins were sutured to the skin margins of the socket. It was felt that the flap would not remain adherent to the walls until

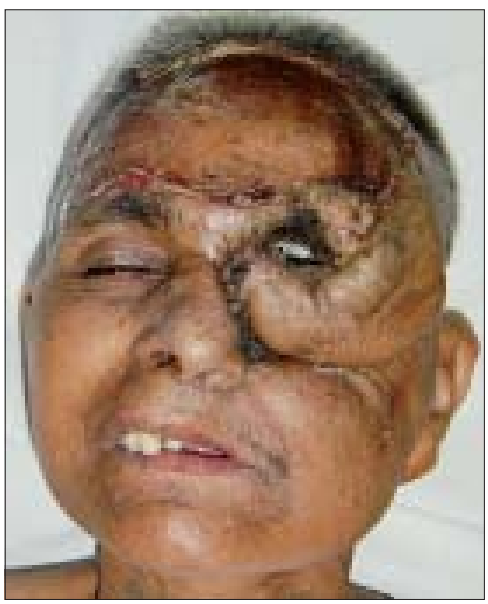

Figure 1: Detached forehead flap with pus discharge Indian J Plast Surg January-June 2008 Vol 41 Issue 1 


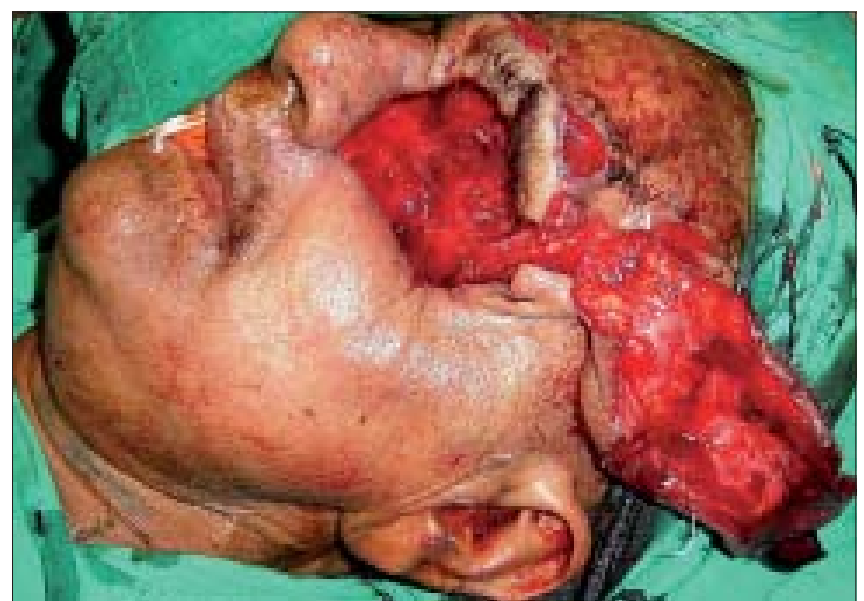

Figure 2: Detachment of forehead flap and removal of dirty granulation tissue

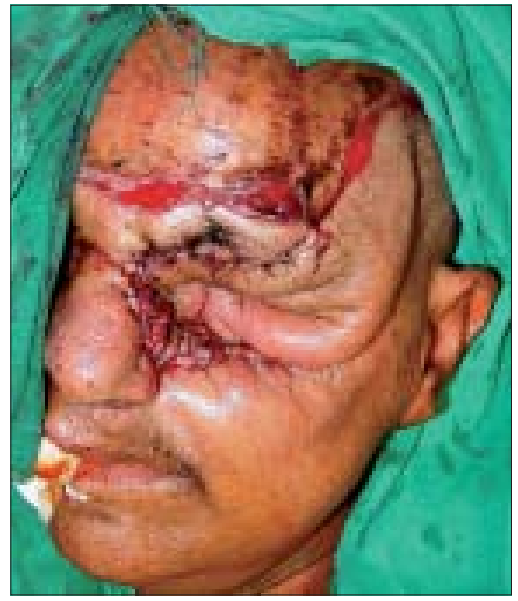

Figure 3: Resuturing of forehead flap to the edges

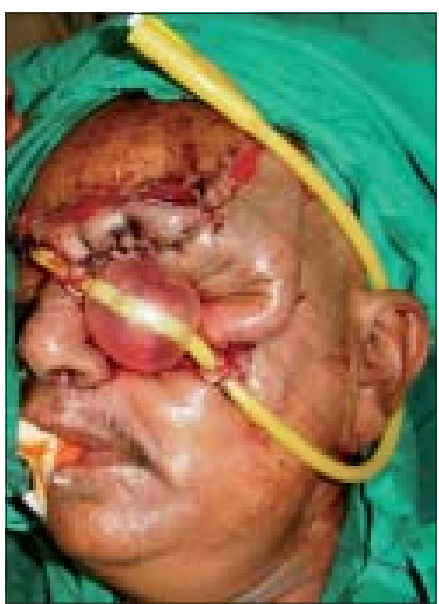

Figure 4: Positioning of Foley's balloon and adjustment of proper pressure

complete healing took place unless some compression was used. To keep the flap in position, a Foley's catheter was used. The catheter was passed through the adjoining normal skin and the bulb was positioned in such a way that the inflated bulb produced a gentle compression

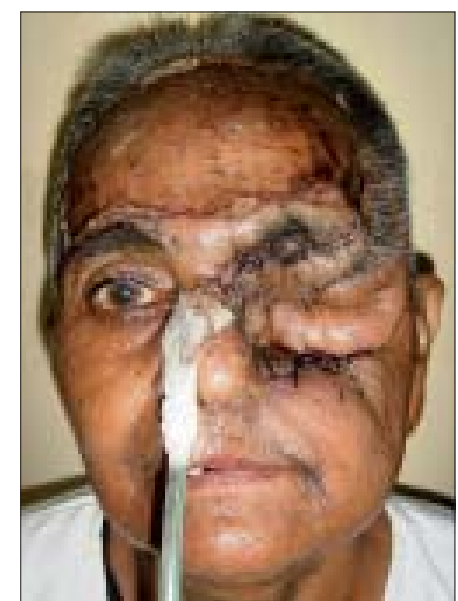

Figure 5: Well-adhered flap with good healing - AP view

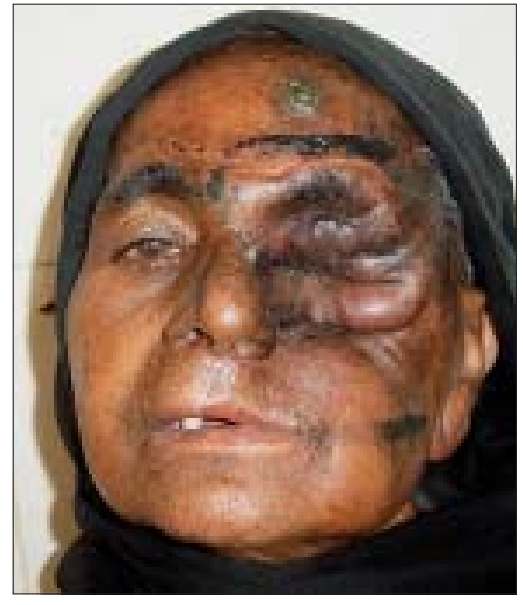

Figure 6: Well-adhered flap with good healing

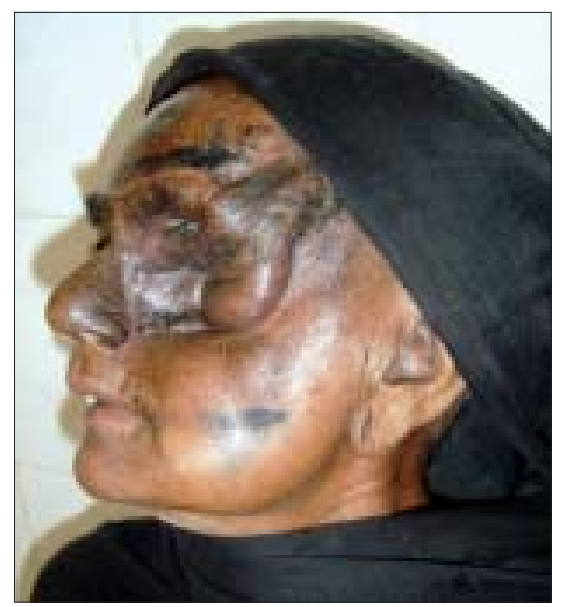

Figure 7: Well-adhered flap with good healing - lateral view

[Figure 4]. The compression was just enough to keep the flap in position until complete healing occurred. Radiotherapy was then started on the $15^{\text {th }}$ postoperative day. The follow-up showed complete coverage of the socket with a well-adhered flap [Figures 5-7]. 


\section{DISCUSSION}

The catheter invented by American urologist Frederic Eugene Basil Foley is a really versatile invention. ${ }^{[1]}$ Although it was intended for urinary drainage, people have found multiple uses for the catheter. Apart from its use as a drainage device, the Foley's catheter has been used for the control of traumatic vascular injuries, ${ }^{[2,3]}$ epistaxis, ${ }^{[4]}$ removal of rectal and esophageal foreign bodies, ${ }^{[5]}$ support for zygomatic $^{[6]}$ and orbital floor fractures, ${ }^{[7]}$ intractable maxillary artery bleeding following complex facial fractures, ${ }^{[8]}$ intra operative tissue expansion, ${ }^{[9,10]}$ imperforate hymen ${ }^{[1]]}$ and scrotal reconstructions. ${ }^{[12]}$ The use of the Foley's catheter in our case as a compression dressing is another extension of the some.

Filling a cavity with dental material, dressing material or tie-over dressing are old methods to apply pressure, which often cannot be sustained. Also importantly, the circulation to the flap cannot be monitored. The same is true for pressure bandages and tapes. Vacuumassisted wound closure (VAC) is also a good method but unfortunately, it is costly and not widely available. ${ }^{[13,14]}$

The above method is very effective in filling a cavity. It increases contact between the surfaces and produces effective pressure to prevent any fluid collection without jeopardizing the circulation. Pressure can be adjusted simply by adding or withdrawing fluid from the balloon. This technique is simple and cost-effective. The desired pressure can be produced on the flap and sustained so that pressure necrosis can be prevented. Needless to say, a Foley's catheter is most easily available anywhere.

\section{ACKNOWLEDGMENT}

The authors are thankful to Dr. Mona Kelshikar for her help in preparing this manuscript.

\section{REFERENCES}

1. Zorgniotti AW. Frederic EB Foley: Early development of balloon catheter. Urology 1973;1:75-80.

2. Navsaria P, Thoma M, Nicol A. Foley catheter balloon tamponade for life-threatening hemorrhage in penetrating neck trauma. World J Surg 2006;30:1265-8.

3. Gilroy D, Lakhoo M, Charalambides D, Demetriades D. Control of life-threatening haemorrhage from the neck: A new indication for balloon tamponade. Injury 1992;23:557-9.

4. Holland NJ, Sandhu GS, Ghufoor K, Frosh A. The Foley catheter in the management of epistaxis. Int J Clin Pract 2001;55:14-5.

5. Beg MH, Ansari MM, Reyazuddin, Mansoor T. Use of Foley catheter in the removal of marble from the esophagus. Indian $\mathrm{J}$ Pediatr 1990;57:273-4.

6. Gutman D, Laufer D, Neder A. The use of the Foley catheter in the treatment of zygomatic bone fractures. $\mathrm{Br} \mathrm{J}$ Oral Surg 1965;3:153-7.

7. Bernal Sprekelsen M, Welkoborsky HJ. Fractures of the orbital floor: Review of 346 cases. Acta Otorrinolaringol Esp 1991;42:1-9

8. Hashim HA, Atiyeh BS, Kayle DI, Dandan I. Intra maxillary sinus balloon compression for intractable post traumatic maxillary artery bleeding. Scand J Plast Reconstr Hand Surg 1999;33:321-4.

9. Abramo AC, Viola JC, Angelo AJ. Intraoperative rapid expansion in cleft palate repair. Plast Reconstr Surg 1993;91:441-5.

10. Johnson TM, Brown MD, Sullivan MJ, Swanson NA. Immediate intraoperative tissue expansion. J Am Acad Dermato 1990;22:283-7.

11. Garden AS, Bramwell R. Treatment of imperforate hymen by application of Foley catheter. Eur J Obstet Gynecol Reprod Biol 2003;106:3-4

12. Chadha A, Saraiya H. Scrotal reconstruction using Foley catheters as tissue expanders. Ann Plast Surg 1991;26: 291-2.

13. Mullner T, Mrkonjic L, Kwasny $\mathrm{O}$, Vecsei $\mathrm{V}$. The use of negative pressure to promote the healing of tissue defects: A clinical trial using the vacuum sealing technique. $\mathrm{Br} \mathrm{J}$ Plast Surg 1997; 50:194-9.

14. Argenta LC, Morykwas MJ. Vacuum-assisted closure: A new method for wound control and treatment: Clinical experience. Ann Plast Surg 1997;38:563-77.

Source of Support: Nil, Conflict of Interest: None declared. 